Int. J. Dev. Biol. 48: 993-1001 (2004)

doi: $10.1387 / \mathrm{ijdb} .041879 \mathrm{ma}$

\title{
Retinal stem cells in vertebrates: parallels and divergences
}

\author{
MARCOS A. AMATO, EMILIE ARNAULT and MURIEL PERRON* \\ Laboratoire d'Embryologie Moléculaire et Expérimentale, UMR 8080, Université Paris XI, Orsay, France
}

\begin{abstract}
During the development of the nervous system, after a given number of divisions, progenitors exit the cell cycle and differentiate as neurons or glial cells. Some cells however do not obey this general rule and persist in a progenitor state. These cells, called stem cells, have the ability to self-renew and to generate different lineages. Understanding the mechanisms that allow stem cells to "resist" differentiating stimuli is currently one of the most fascinating research areas for biologists. The amphibian and fish retinas, known to contain stem cell populations, have been pioneering models for neural stem cell research. The Xenopus retina enabled the characterization of the genetic processes that occur in the path from a pluripotent stem cell to a committed progenitor to a differentiated neuron. More recently, the discovery that avian and mammalian retinas also contain stem cell populations, has contributed to the definitive view of the adult nervous system of upper vertebrates as a more dynamic and plastic structure than previously thought. This has attracted the attention of clinicians who are attempting to employ stem cells for transplantation into damaged tissue. Research in this area is promising and will represent a key instrument in the fight against blindness and retinal dystrophies. In this review, we will focus primarily on describing the main characteristics of various retinal stem cell populations, highlighting their divergences during evolution, and their potential for retinal cell transplantation. We will also give an overview of the signaling cascades that could modulate their potential and plasticity.
\end{abstract}

KEY WORDS: retina, neurogenesis, stem cell, proliferation, differentiation, transplantation

\section{Introduction}

The vertebrate nervous system is probably one the most complex structures known so far. It is composed of thousands of different cellular populations very precisely positioned and capable of finely regulated interactions. Such complexity derives from a relatively small number of neuroectodermal progenitors that adopt a neural fate during neurulation. These cells represent the origin of the neural diversity and, through a sequence of differential gene expression and regulation they undertake different lineages. In the retina, differentiation begins soon after eye vesicle evagination and proceeds during the embryonic development.

In fish and amphibians, neurogenesis does not cease after the embryonic stage, but continues to take place throughout the animal's life. The retina continues to grow and new cells are added continually in the stem cell containing zone, a region known as ora serrata, ora terminalis, ciliary marginal zone (CMZ) or circumferential germinative zone (CGZ) (Johns, 1977; Straznicky and Gaze, 1971). The re-investigation of the proliferative state of retinal cells in chick led to the discovery that a proliferative ora serrata also exists in birds (Fischer and Reh, 2000; Kubota et al., 2002). Moreover, the presence of a potential retinal stem cell population within the ciliary epithelium of rodents has recently been reported (Ahmad et al., 2000; Tropepe et al., 2000, reviewed in Perron and Harris, 2000; Reh and Fischer, 2001). This has attracted the interest of clinicians aiming to develop retinal stem cell transplantation therapies for the treatment of retinopathies. It remains crucial however to characterize these cells at a molecular level and define their potential and plasticity in different cellular environments. In this review, we will present an overview of the different sources of retinal stem cells in different species and of the recent progress made at the molecular level. In the second part of this article we will focus on the therapeutic possibilities for stem cell transplantation in the retina.

\section{Ora serrata in fish and amphibians}

Teleost fish and amphibians represent important models to study post-embryonic neurogenesis, because they grow throughout their lifespan. As a consequence, there is an increase in size

Abbreviations used in this paper: CGZ, circumferential germinative zone; CMZ, ciliary marginal zone; GCL, ganglion cell layer; INL, inner nuclear layer; ONL, outer nuclear layer; RPE, retinal pigment epithelium.

\footnotetext{
*Address correspondence to: Dr. Muriel Perron. Laboratoire d'Embryologie Moléculaire et Expérimentale, UMR 8080, Bâtiment 445, Université Paris XI, 91405 Orsay, France. Fax: +33-169-156-802. e-mail: muriel.perron@ibaic.u-psud.fr
} 

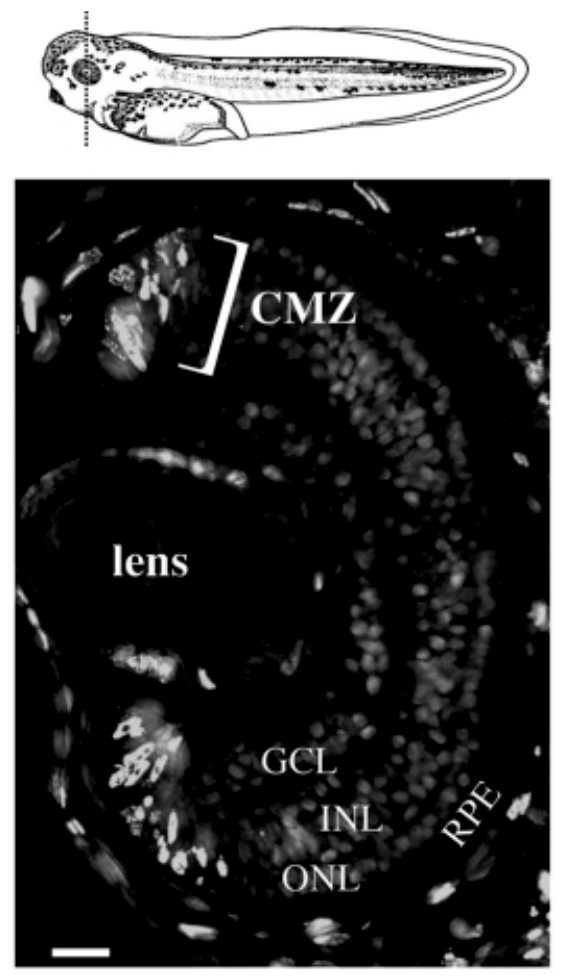

Fig. 1. The ciliary marginal zone in Xenopus tadpole retina. A transversal cryostat section showing BrdU uptake in the ciliary marginal zone (CMZ) of stage 41 tadpole Xenopus embryo. GCL, ganglion cell layer; INL, inner nuclear layer, ONL, outer nuclear layer, RPE, retinal pigment epithelium. Scale bar, $25 \mu \mathrm{m}$.

in all body structures, including the retina (Johns, 1977). Therefore, the analysis of an adult fish or amphibian retina reveals that the majority of its cells are born after the embryonic period. The principal site of post-embryonic neurogenesis is the ciliary margin, a ring of cells situated in the periphery of the retina (Figs. 1, 2A,B).

The first and most typical characteristic of these cells is their self-renewal ability. It has long been known that this zone is an active site of proliferation. By using birth date indicators, such as ${ }^{3} \mathrm{H}$ thymidine, it has been shown that new rings of cells are constantly added from this zone to the retina, cells situated more peripherally being younger than central ones (Straznicky and Gaze, 1971; Hollyfield, 1971). In the ciliary margin itself there is a spatial gradient of differentiation: at the extreme edge of the CMZ lie the most undifferentiated stem cells, while more centrally are situated committed proliferative neuroblasts, followed by differentiating precursors and finally postmitotic neurons. Strikingly, it has been shown that this spatial order recapitulates the temporal events occurring during embryonic neurogenesis in the central retina (Dorsky et al., 1995; Perron et al., 1998; reviewed by Harris and Perron, 1998). By analyzing gene expression, the Xenopus CMZ has been divided into four principal zones. Gene expression in these different zones recapitulates the sequential expression occurring in retinoblasts during embryonic development (Dorsky et al., 1995; Perron et al., 1998). Retinal stem cells reside in the first zone, while committed retinoblasts and differentiating neurons are found from the second zone onwards.

The second important characteristic of cells situated in the most peripheral zone of the ciliary margin is their multipotency. Indeed, labeling the frog $\mathrm{CMZ}$ cells with a tracer and analyzing their lineages showed that retinal stem cells generate large clones containing all cell types including glial and pigmented cells. Labeling cells more centrally in the CMZ results in reduced clone sizes (Wetts et al., 1989). Again, the similarities with embryonic retinogenesis are remarkable: labeling early embryonic retinal precursors by using the lipofection technique (Holt et al., 1990; Ohnuma et al., 2002b) results in large clones containing all retinal cell types, while lipofecting at later stages results in smaller clones composed mainly of late born cells (Moore et al., 2002).

In amphibians, ciliary marginal cells participate in the regeneration process after retinal injury (Keefe, 1973; Reh and Nagy, 1987). The plasticity of ciliary marginal stem cells has been demonstrated after injury of particular retinal cell types. For example, selectively killing dopaminergic amacrine neurons by injecting a neurotoxin in the eyes of Ranastimulates the production of this specific cell type (Reh and Tully, 1986). Similarly, ablation of glutaminergic cells with kainic acid results is an increased production of those cells from the CMZ (Reh, 1987).

\section{Potential stem cells in the teleost central retina}

In contrast to the amphibian retina, in which retinal precursors generate all retinal cell types, fish rod photoreceptors are generated during embryogenesis in a secondary wave of neurogenesis by specialized rod precursors situated in the outer nuclear layer (ONL). Similarly, in the post-embryonic fish, rods are not produced together with the other retinal cell types at the ciliary margin (reviewed in Otteson and Hitchcock, 2003). Consequently, the newly generated ONL, close to the ciliary margin, contains only cone photoreceptors. More centrally, the photoreceptor layer contains cones, rods and dividing rod precursors. It has been shown that rod precursors derive from a mitotic population of elongated cells in the underlying inner nuclear layer (INL) that migrate to the ONL (Johns, 1982, Julian et al., 1998). These fusiform progenitors have a restricted lineage as they only generate rods. They probably derive from a slow dividing population of spherical cells that have been found in the inner part of the INL (Fig. 2B; Otteson et al., 2001). These cells have some stem cell characteristics, i.e. they self renew and divide asymmetrically. Therefore, there would be two spatial differentiation gradients in the fish retina: the first, a peripheral to central gradient, concerning all lineages except rods, located in the margin, with stem cells at the peripheral edge and committed precursors and differentiating neurons more centrally; the second, an internal to external gradient, concerning exclusively the rod lineage, with stem cells in the inner part of the INL, and rod precursors in the ONL.

Regeneration studies have demonstrated that the INL stem cell population consists of multipotent cells. Indeed, removing part of the retina by surgical lesion triggers a regenerative response in the INL and the ONL with the formation of a regenerative blastema made of radially elongated cells that surround the lesioned area (Hitchcock et al., 1992). This blastema behaves like a ciliary margin and fills the space generated by the lesion (Hitchcock et al., 1992; reviewed in Otteson and Hitchcock, 2003). This experiment demonstrated that INL stem cells that normally generate only rod cells, could, following injury, give rise to other retinal neurons. 


\section{Re-examination of the ora serrata in birds and mammals}

In chicks, by the end of the embryogenesis at the time of hatching, the retina is fully functional and chicks are able to see. As in amphibians and fish, after the embryonic period, the eyes of birds follow the overall growth of the body and increase in size. This expansion is mainly due to growth of the sclera and to passive stretching of the retina and it was thought that no new neurons were added at the retinal periphery. A few cells could however be labeled with ${ }^{3} \mathrm{H}$ thymidine in the most peripheral region of the post-hatch chick retina (Morris et al., 1976). Fischer and Reh have more recently re-examined this proliferating marginal zone in postnatal chicks and found that these cells produce neurons (Fig. 2C; Fischer and Reh, 2000). Post-hatched quails also exhibit a proliferative ciliary margin (Kubota et al., 2002). However there are some differences between bird and lower vertebrate ciliary marginal cells. First of all, chick CMZ cells appear to have a more restricted potential, as they normally generate only bipolar and amacrine interneurons but not ganglion cells or photoreceptors (Fischer and Reh, 2000). Second, unlike in fish and amphibians, the post-natal chick $\mathrm{CMZ}$ does not participate in the regeneration process observed following injury (Fischer and Reh, 2000).

In placental mammals a proliferating ciliary margin does not exist (Kubota et al., 2002). However, a rudimentary CMZ has been found in newborn opossums showing that these marsupials share some similarities with birds and reptiles (Kubota et al., 2002).

\section{Potential stem cells in the ciliary body}

Adjacent to the ciliary margin, between the retina and the iris, there is a structure derived from the optic cup called the ciliary body (Fig. 2 C,D). Its epithelium is composed of two cell layers, a pigmented epithelium, which is the prolongation of the retinal pigment epithelium and a cuboidal non-pigmented epithelium that secretes the aqueous humor and glycoproteins of the vitreous body. In chick, the ciliary body can be subdivided in two zones: the pars plana in close proximity to the ciliary margin and the pars plicata, situated between the pars planaand the iris (Fig. 2C). It has recently been shown that the non-pigmented epithelium of the ciliary body of the chick retina contains quiescent stem cells (Fischer and Reh, 2003a). These cells do not normally proliferate but when stimulated with growth factors, they undergo proliferation and are able to produce neurons. Strikingly, these cells can generate ganglion cells while ciliary marginal cells, as described above, generate only amacrine and bipolar interneurons. In chick, ganglion cells are the first cell type to differentiate while bipolar cells, together with rod photoreceptors and Müller glial cells, are the last retinal cell types to be born. This difference in neural types obtained from the ciliary body and from the ciliary margin tends to suggest that a gradient of multipotency could exist in peripheral chick retina with most primitive and non-restricted cell in the ciliary body capable of generating early cell types, and more restricted precursors in the ciliary margin competent to generate only later cell types (Fischer and Reh, 2003a).

In adult placental mammals, it is assumed that there is no proliferation in the neural retina (Ahmad et al., 2000; Kubota et al., 2002). Nonetheless, even if a proliferating ciliary margin is absent, some cells continue to proliferate in vivo in the pigment epithelium of the ciliary body in few-week-old rats and mice (Ahmad et al., 2000; Kubota et al., 2002). In adult rodents, it has been shown that cells dissected out from this part of the eye and cultured in vitro, are able to clonally expand and to proliferate either with or without the addition of growth factors (Tropepe et al., 2000; Ahmad et al., 2000). When mouse pigmented ciliary body cells are cultured in
Fig. 2. Localisation of retinal stem cells in various vertebrates. Schema illustrating the position of stem cells in Xenopus tadpole (A), fish (B), post-hatched chick (C) and adultmouse (D) retinas. Multipotent retinal stem cells are found in the most peripheral zone of the ciliary marginal zone of Xenopus, zebrafish and chick retinas. Stem cells specialized in rod production may be present in the inner nuclear layer of fish retina. Another source of retinal stem cells in the chick retina, under special conditions (see text for details) are found in the nonpigmented region of the pars plana and pars plicata. In the adult mouse retina, cells with stem cellproperties when cultured in vitro are found in the pigmented ciliary epithelium. $C M Z$, ciliary marginal zone; GCL, ganglion cell layer; INL, inner nuclear layer, IPL, innerplexiformlayer; ONL, outer nuclear layer, OPL, outer plexiform layer; $P C M$, pigmented ciliary margin; $R P E$, retinal pigment epithelium.
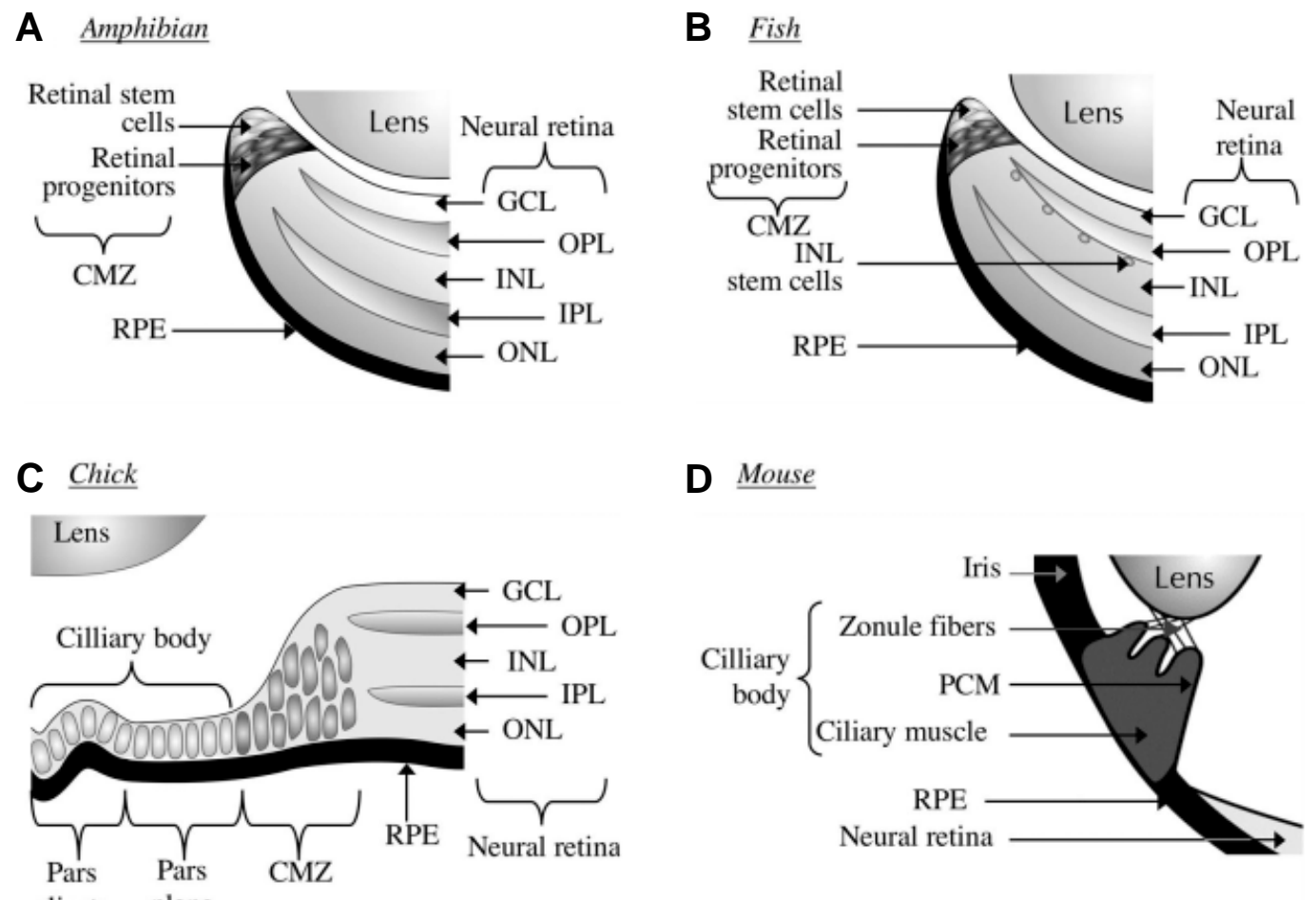

plicata plana 
vitro, they initially form small spherical colonies containing pigmented cells. If these colonies are dissociated and the cells cultured again, they are able to self-renew, forming secondary colonies, at least for six generations (Tropepe et al., 2000). By immuno-labelling with specific markers of retinal cell types it has been shown that colony forming cells are multipotent as they can give rise to different retinal cell types, including rod photoreceptors, bipolar neurons, and Müller glia. Altogether these data demonstrate the presence in the pigmented ciliary epithelium of a few cells with retinal stem cell characteristics.

\section{Other potential sources of neurogenesis in the adult retina}

Besides stem cells situated in the $\mathrm{CMZ}$ or in the ciliary body (see above), there are other sources of potential retinal stem cells. The existence of these cells has been unveiled by regeneration studies. It has been shown that retinal injury triggers a proliferative response in all vertebrates. This proliferation wave is followed by the generation of new neurons in fish,amphibians and birds, even if these processes occur with different characteristics (reviewed in Reh and Fischer, 2001). In amphibians, we saw above that the $\mathrm{CMZ}$ contributes to part of the regeneration process but the RPE represents the most important source of regeneration. Indeed, following retinal damage, RPE cells lose their pigmentation, dedifferentiate and eventually generate neurons through a process called transdifferentiation or metaplasia.

The RPE however does not have such a regeneration potential in fish (reviewed in Raymond and Hitchcock, 2000). The potential of Müller glia cells has been investigated since recent studies revealed a neural progenitor capacity of glia in the central nervous system (reviewed in Goldman, 2003). During development, for example, radial glial cells give rise to both neurons and astrocytes (Malatesta et al., 2000; Noctor et al., 2001; reviewed by Gotz et al., 2002). In addition, in the adult mouse subventricular zone, there are stem cell populations made by astrocyte like cells (Doetsch etal., 1999). In the fish retina, some studies suggest that indeed Müller glial cells could also take part in the regenerative process, even though there is no direct evidence that they give rise to neurons (Braisted et al., 1994; Raymond and Hitchcock, 1997; Wu et al., 2001). However, this has recently been demonstrated in the chick retina (Fischer and Reh, 2003b). After injecting postnatal chick eyes with neurotoxins, Müller cells re-enter the cell cycle and migrate to the ONL where, after a few days, they lose glial specific markers and begin to express retinal progenitor markers (Fischer and Reh, 2001). Some of these cells differentiate as new neurons or glial cells but the majority retain undifferentiated characteristics. It has been shown that the types of neurons that are generated are influenced by the kind of neurons that have been destroyed (Fischer and Reh, 2001). Interestingly, the ability of Müller cells to respond to toxic damages seems to decrease after the initial period of postnatal life in cells situated in the central retina, while it is conserved in the peripheral regions (Fischer and Reh, 2001). Chick Müller cells can be induced to proliferate and differentiate into neurons in response to growth factors (see below). In mammals, after retinal injury, Müller cells undergo abnormal proliferation known as reactive gliosis (Humphrey et al., 1993; MacLaren, 1996; Dyer and Cepko, 2000). Altogether, these data indicate that glial cells in the retina, as in other regions of the vertebrate CNS retain a high degree of plasticity.
TABLE1

\section{SOURCES OF ADULT NEUROGENESIS IN VERTEBRATE RETINAS}

\begin{tabular}{|c|c|c|c|c|}
\hline localization & model & $\begin{array}{l}\text { proliferation } \\
\text { capacity }\end{array}$ & $\begin{array}{l}\text { self-renewal } \\
\text { ability }\end{array}$ & multipotentialy \\
\hline \multirow[t]{3}{*}{$\mathrm{CMZ}$} & amphibians & ++ & ++ & ++ \\
\hline & fish & ++ & ++ & ++ \\
\hline & birds & + & $\begin{array}{l}\text { at least a few weeks } \\
n \text { posthatched chicks }\end{array}$ & + \\
\hline $\begin{array}{l}\text { slow dividing } \\
\text { INL cells }\end{array}$ & fish & + & ++ & $\begin{array}{l}\text { following retinal } \\
\text { injury }\end{array}$ \\
\hline \multirow[t]{2}{*}{ ciliary body } & birds (NPE) & $\begin{array}{l}\text { when stimulated } \\
\text { with growth factors }\end{array}$ & $?$ & $\begin{array}{l}\text { when stimulated } \\
\text { with growth factors }\end{array}$ \\
\hline & $\begin{array}{l}\text { mammals } \\
(\mathrm{PCM})\end{array}$ & in vitro & in vitro & in vitro \\
\hline \multirow[t]{3}{*}{ Müller cells } & fish & following retinal injury & $?$ & $?$ \\
\hline & chick & $\begin{array}{l}\text { following retinal } \\
\text { injury or when } \\
\text { stimulated } \\
\text { with growth factors }\end{array}$ & $?$ & $\begin{array}{l}\text { following retinal } \\
\text { injury or when } \\
\text { stimulated } \\
\text { with growth factors }\end{array}$ \\
\hline & mammals & following retinal injury & $?$ & $\begin{array}{l}\text { following retinal } \\
\text { injury }\end{array}$ \\
\hline
\end{tabular}

NPE: non pigmented epithelium; PCM: pigmented ciliary margin

A recent study showed that adult rat iris tissue, which is embryonically related to the neural retina, can generate cells expressing neuronal markers when cultured in the presence of a growth factor (Haruta et al., 2001). Iris-derived cells can also be forced to differentiate into rod photoreceptor if the Crxphotoreceptor specific homeobox gene is expressed, which was not observed in the adult hippocampus-derived neural stem cells (Haruta et al., 2001). This highlights the specific potential of iris cells to become retinal neurons.

\section{Actual stem cells versus potential stem cells}

During this review we often employ the term 'retinal stem cells' to designate cells that are a source of postnatal or adult retinogenesis (Table 1). However, if we consider the strict definition of stem cells, i.e. self renewal, asymmetric cell division, ability to regenerate adult tissues, multipotency and slow division time, the term 'retinal stem cells' should only be employed concerning cells in the ciliary margin of fish and amphibians. In chick, given that proliferation carries on for at least a few months after birth in the ciliary margin, and that at least two types of interneurons are added to the retina, it is likely that a stem cell population also exists in the chick CMZ. On the other hand, the slowly dividing cell population found in the INL of fish, does not satisfy the multipotency criteria as it has been suggested that it produces only rod precursors. Nevertheless, these cells retain this potential since they become multipotent after retinal injury. In the ciliary body of chicks and rodents, there are cell populations that are normally non-mitotic and fully differentiated. Therefore, these cells do not match any stem cell characteristics. However, we saw above that under certain conditions (addition of growth factor or in vitro experiment), these cells have the capacity to dedifferentiate and display stem cell characteristics. As these cells have conserved only the potential to behave as stem cells, we have referred to these cells as "potential stem cells". 


\section{Molecular aspects of retinal stem cell maintenance and plasticity (Fig. 3)}

The existence of stem cell niches inside a differentiated tissue requires these cells to respond differently to environmental cues compared to their neighbors. The ability to respond to different cues is an intrinsic property of the cells and depends on the genes they express. In the frog CMZ, although many genes are known to be expressed in retinal progenitors, relatively very few are known to be expressed in retinal stem cells (Perron et al., 1998). It is likely that retinal identity of retinal stem cells is given by the expression of eye-specific homeobox transcription factors. The homeobox gene Pax6 for example is expressed in retinal stem cells of the CMZ in Xenopus (Perron et al., 1998), fish (Hitchcock et al., 1996) and chick (Fischer and Reh, 2000). Interestingly Pax6is also found in the fish stem cells of the INL (Otteson et al., 2001). Altogether these data suggest that retinal stem cells constantly express the homeobox gene Pax6. It has recently been shown that Pax6 controls the multipotent state of retinal precursors. Indeed, a conditional mutation of Pax 6 in the eye restricts the lineage of retinal progenitors that generate only amacrine cells (Marquardt et al., 2001). Another marker that has been found recurrently expressed in retinal stem cells is Chx10 (in chick: Fischer and Reh, 2000, in fish: Levine et al., 1997; in mouse: Tropepe et al., 2000, Ahmad et al., 2000, in Xenopus: M. Andreazzoli and F. Cremisi, personal communication). Mutations in this gene have been associated with human and murine microphtalmia (Ferda Percin et al., 2000, Burmeister et al., 1996) and with impaired retinal proliferation (Burmeister et al., 1996). Despite the differences among the various classes of retinal stem cells analysed above, they all seem to posses a common intrinsic characteristic given by the expression of the homeobox genes, Pax6and Chx10, as well as by the absence of markers of differentiated neurons. It is likely that Pax6 and Chx10 contribute to determine the retinal identity of these cells. $R \times 1$ and $X O p t \times 2$ are also expressed in the most peripheral region of the Xenopus $\mathrm{CMZ}$ where stem cells reside (Perron etal., 1998). These homeobox genes, considered to form part of the eye master regulator genes group, are the first to be expressed in the presumptive eye territory at the gastrula stage and their overexpression can drive the formation of ectopic eyes (for recent studies see Zuber et al., 2003). $R \times 1$ and XOptx2 are transcription factors that control the proliferation of retinal precursors (Casarosa et al., 2003; Zuber et al., 1999). It is important to note that these homeobox genes (Pax6, Chx10, Rx 1and XOptx 2) are not expressed exclusively in the stem cell containing region but extend also to progenitors as well as some differentiated retinal neurons (Perron etal., 1998; Mathers etal., 1997; Zuber et al., 1999; M. Andreazzoli and F. Cremisi, personal communication).

There is increasing interest in the role played by RNA-binding proteins during neurogenesis. Drosophila Musashi is one of the neural RNAbinding proteins essential for neural development and is required for asymmetric cell divisions in adult sensory organ development (Okabe et al., 2001). In mammals, two members of this family, Musashi1 (Msil) and Musashi2 (Msi2), are strongly coexpressed in neural precursor cells, including CNS stem cells (Sakakibara et al., 1996; Sakakibara et al., 2001). It has been suggested that Msi1 andMsi2 are cooperatively involved in the proliferation and maintenance of CNS stem cell populations (Sakakibara et al., 2002). Interestingly, we have found that homologues of the Musashi family of RNA-binding proteins in Xenopus, $n r p-1$ and $x r p 1$, are expressed in retinal stem cell in Xenopus CMZ (M.A.A. and M.P., unpublished data). It now remains to investigate their role in these cells.

In contrast to precursors that are a fast-dividing cell population, retinal stem cells divide at a much slower rate. An extreme case is represented by INL stem cells in fish that are revealed only after several days of BrdU exposure (Julian et al., 1998, Otteson et al., 2001). As a consequence, stem cells and precursors express cell cycle machinery genes differently. This has been highlighted in the Xenopus retina where cyclins and cyclin dependent kinases are weakly expressed in the most peripheral region of the ciliary margin compared to the more central region (Ohnuma et al., 2002a).

Recently, we have shown that some downstream components of the hedgehog $(\mathrm{Hh})$ cascade, Gli2 and Gli3transcription factors as well as smoothened (Smo), a transmembrane protein, are strongly expressed in the stem cell region of the ciliary margin (Perron et al., 2003). In contrast to the transcription factors described above, these genes are specifically expressed in this region and not in the more central $\mathrm{CMZ}$ or differentiated neurons. Gli2, Gli3 and Smo thereby represent specific retinal stem cell

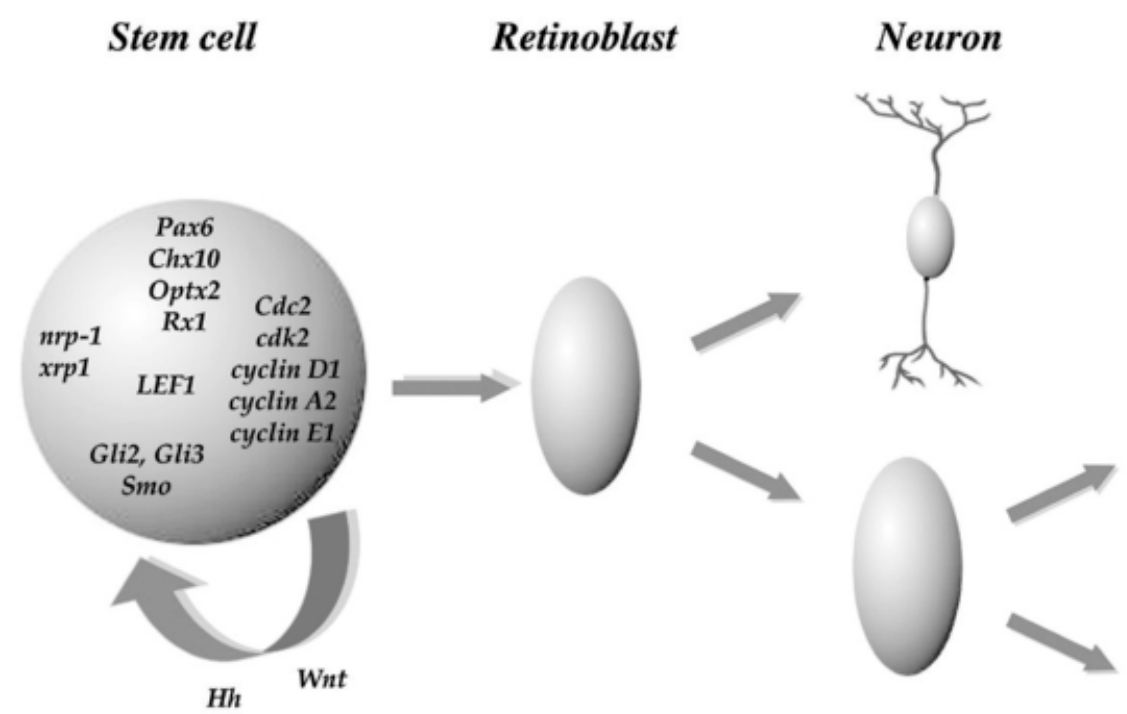

Fig. 3. Molecular aspects of retinal stem cells. Schema displaying the genes known to be expressed in retinal stem cells and the signalling molecules that may be involved in maintaining the pool of these cells. Transcription factors Pax6 and Chx 10 have been found in retinal stem cells of various species. Xopt $\mathrm{2} 2$ and $\mathrm{Xr \times 1}$ are expressed in retinal stem cells in the Xenopus CMZ. Post-transcription factors of the musashi family are also expressed in Xenopus retinal stem cells. Cell cycle genes (cdc2, cdk2, cyclin D1, cyclin A2, cyclin E1) are expressed at a very low level in the most peripheral zone of the Xenopus CMZ. Components of the Hedgehog (Smo, Gli2 and Gli3) and Wnt (LEF1) signalling pathways have been found in the CMZ in Xenopus and chick retina, respectively. These two cascades may be involved in promoting the proliferation of these retinal stem cells (see text for details). 
markers. Previous in vitroexperiments showed that Sonichedgehoh (Shh) increases the proliferation of mouse retinal embryonic precursor cells (Jensen and Wallace 1997). In accordance with this data, we found that blocking the Hh cascade in vivo with cyclopamine results in a dramatic reduction of the proliferating cells in the $C M Z$ in Xenopus (M.A.A and M.P., unpublished results). Therefore, a long range $\mathrm{Hh}$ signal, from the ganglion cells and/or from the central RPE (Perron et al., 2003) may instruct stem cells and precursors to maintain a proliferative state. A hint in this direction is given by recent data, which demonstrated that Shh regulates adult neural proliferation (Lai et al., 2003) and is required to maintain stem cell niches in the adult brain (Machold et al., 2003).

It has recently been reported that $W n t 2 b$, a member of the $W n t$ signaling molecule family could also control the proliferation of retinal stem cells (Kubo et al., 2003). Retinal progenitor cell proliferation was promoted in vitro in the presence of Wnt2b while blocking the Wnt pathway in vivo using a dominant negative form of LEF1, a downstream Wnt signaling component expressed in the CMZ, inhibited the proliferation of the cells (Kubo et al., 2003). These results suggest that $W n t 2 b$ plays a role in the maintenance of retinal stem cells. The similarities between $\mathrm{Hh}$ and Wnt actions on retinal stem cells suggest some possible crosstalk between these two pathways. This possibility is supported by the fact that, in Xenopus, Wnt signals are targets and mediators of Gli proteins (Mullor et al., 2001). For example, the injection of Gli2 in early frog embryo induces ectopic Wnt8expression in animal caps (Mullor et al., 2001). Wnt and Hh signaling cascades could therefore act in concert for the maintenance of retinal stem cells. It has been suggested that the bone morphogenetic proteins (BMPs) are implicated in the formation of the ciliary body (Zhao et al., 2002). $B m p 4$ and $B m p 7$ are indeed expressed in the developing ciliary epithelium in mouse (Zhao et al., 2002). Transgenic mice expressing Noggin, a BMP antagonist, in the lens, fail to develop the ciliary body and this defect is rescued by co-expression of BMP7 (Zhao et al., 2002). The specific role of this signaling molecule on the ciliary body potential stem cells is not known however. In the chick ciliary body, it seems that BMPs are not involved in the proliferation of the potential stem cell population since intraocular injections of Noggin does not have any effect on the proliferation of these cells (Fischer and Reh, 2003a).

Extrinsic signals as growth factors can influence retinal cells in various ways. Studies in different vertebrates have shown that retinal progenitors strongly increase their proliferation in response to insulin/IGF (reviewed by Otteson and Hitchcock, 2003). Studies in fish have shown that IGF1 and IGF2 also stimulate the proliferation of cells situated at the ciliary margin (Boucher and Hitchcock, 1998) and in rod precursors (Mack and Fernald, 1993). IGF1 also increases cell division in the chick CMZ (Fisher and Reh 2000). It is interesting to note that some other growth factors, such as transforming growth factor-alpha (TGF- $\alpha$ ), do not act as mitogens on CMZ cells (Reh and Nagy, 1989; Boucher and Hitchcock, 1998). Regional differences in the responsiveness to insulin and FGF2 have been found in the chick stem cells of the ciliary body. Indeed, it has been demonstrated that insulin increases the proliferation in the pars plana, the region adjacent to the ciliary margin, while FGF2 exerts the same effect on the pars plicata, adjacent to the iris. The combination of these two factors increases proliferation in both the pars plana and plicata and in the ciliary margin (Fischer and Reh, 2003a). The combined action of these factors is more than a simple proliferative signal but has wider and more unexpected effects. It has been shown indeed that the combination of insulin and FGF2 promotes the generation of neurons in the non pigmented epithelium of the ciliary body and influences the types of neurons that are generated in the ciliary margin (Fischer and Reh, 2003a). Moreover, the combination of these two factors induces Müller glial cells to proliferate and produce new neurons even in absence of retinal damage (Fischer et al., 2002). FGF2 is also required for the in vitro proliferation of rat ciliary body pigmented cells (Ahmad et al., 2000) and facilitates the formation of neurospheres in mouse (Tropepe et al., 2000). These data highlight the potential of exogenous growth factors to stimulate stem cells and Müller glia proliferation and to regenerate neurons.

\section{Cell-replacement therapy}

Retinal degeneration and dystrophies are major causes of blindness and are often characterized by apoptotic death of the photoreceptor cell layer of the retina, such as in retinitis pigmentosa and age-related macular degeneration (Gavrieli et al., 1992; Lolley et al.,1994). Attempts to repopulate the retina with grafted neurons have been quite unsuccessful because of limited integration of donor cells into the host retina (Aramant and Seiler, 1995; Silverman et al., 1992; Berson and Jakobiec, 1999, Kwan et al., 1999). Due to the high plasticity of stem cells, stem cell therapies may hold enormous potential for replacement of degenerated photoreceptors (reviewed in Ahmad, 2001). It has been shown that retinal stem cells isolated from the embryonic retina express photoreceptor specific markers following transplantation into the subretinal space of rats (Chacko et al., 2000). The discovery of potential retinal stem cells in the pigmented ciliary margin (Tropepe et al., 2000, Ahmad et al., 2000, see above) offered new perspectives for a substrate for retinal regeneration. These stem cells, isolated from the ciliary epithelium of adult rats and transplanted into eyes with retinal injury, also integrated into the host retina and some expressed photoreceptor markers (Chacko et al., 2003).

However, extraction of retinal stem cells from the pigment ciliary margin involves complicated microsurgical procedures, and the limited availability of retinal stem cells means that this approach may not be an option for stem cell therapy (Kicic et al., 2003). The possibility of using other sources of stem cells for transplantation into the retina for retinal regeneration has therefore been investigated. Concerning adult stem cell transplantation, it has been shown that adult rat hippocampus-derived neural stem cells can be successfully transplanted into neonatal retinas, where they differentiate into neurons and glia, but they cannot integrate into adult retinas (Takahashi et al., 1998). The age of the host retina seems to play a key role in the efficiency of stem cell integration (Van Hoffelen et al., 2003). It was however reported that the incorporation and subsequent differentiation of the grafted hippocampusderived neural stem cells into neuronal and glial lineage, including the formation of synapse-like structures, can be achieved in the adult rat retina after mechanical injury or in mature dystrophic rats (Nishida et al., 2000; Young et al., 2000). These results show that the integration and neuronal differentiation is enhanced by ongoing degeneration in the host eye. More recently, it has been demonstrated that the transplantation of adult bone marrow stem cells into the adult rat eye, with (Tomita et al., 2002) or without (Kicic et al., 2003) mechanical injury, leads to the differentiation of these cells into photoreceptors in the host retina. These results raise the possibility that some stem cells have the ability to differentiate into 
retinal neural cells and could help repair damaged retinas. A new perspective is also offered by the iris tissue, which, as we described above, retains the potential to give rise to retinal neurons (Haruta et al., 2001). In addition, this tissue can be feasibly obtained surgically thereby providing a source of autologous transplant.

\section{Conclusions}

The development of new techniques this last decade has given rise to an explosion of new data that reveal the presence of neural stem cells in different regions of the adult CNS (reviewed in Galli et al., 2003; Arlotta et al., 2003). Also, unexpected is the recent finding of stem cells in the adult retina of species other than fish and amphibians. Although much progress has been made lately, the rapid pace of retinal stem cell discoveries these last few years implies that we still know very little about their molecular characteristics. It will however be crucial to comprehend how signalling pathways act on stem cells to maintain their proliferative state, their differentiation potential, and their plasticity. This knowledge may help to design future stem cell-based retinal transplantation. In the forthcoming years, a systematic approach, taking advantage for example, of the microarrays technique, will be compelling to analyse the complete panel of genes expressed in retinal stem cells. This will certainly constitute a fertile ground to trigger a new impetus of research in this field.

Note added in proof: While this paper was under review, new relevant papers on the subject were published. In particular, it has been shown that in mammals, Müller glial cells also have the capacity to produce neurons when stimulated to proliferate following retinal injury (Ooto et al., 2004). Moreover, by performing a genomic analysis in mouse, Cepko and coll. showed that gene expression profiles of retinal Müller glia and mitotic progenitor cells are highly similar (Blackshaw et al., 2004). Also, Moshiri and Reh (Moshiri and Reh, 2004) have shown that mice heterozygous for the Hedgehog receptor Patched display persistent progenitors at the retinal margin for up to 3 months of age, resembling the ciliary marginal zone of lower vertebrates.

\section{Acknowledgements \\ We are grateful to Tilak Das for comments on the manuscript. This work was supported by an EC Biotechnology grant (QL G3-CT-200101460), an ARC grant and a Retina France Grant to M. P. The EC Biotechnology grant supports M.A.A.}

\section{References}

AHMAD, I. (2001). Stem cells: new opportunities to treat eye diseases. Invest Ophthalmol Vis Sci42, 2743-8.

AHMAD, I., TANG, L. and PHAM, H. (2000). Identification of neural progenitors in the adult mammalian eye. Biochem Biophys Res Commun 270, 517-21.

ARAMANT, R.B. and SEILER, M.J. (1995). Fiber and synaptic connections between embryonic retinal transplants and host retina. Exp Neuro/133, 244-55.

ARLOTTA, P., MAGAVI, S.S. and MACKLIS, J.D. (2003). Induction of adult neurogenesis: molecular manipulation of neural precursors in situ. Ann $N Y$ Acad Sci991, 229-36.

BERSON, E.L. and JAKOBIEC, F.A. (1999). Neural retinal cell transplantation: ideal versus reality. Ophthalmology 106, 445-6.

BLACKSHAW, S., HARPAVAT, S., TRIMARCHI, J., CAI, L., HUANG, H., KUO, W. P., WEBER, G., LEE, K., FRAIOLI, R. E., CHO, S. H. et al. (2004). Genomic analysis of mouse retinal development. PLOS Bio/2, E247.

BOUCHER, S.E. and HITCHCOCK, P.F. (1998). Insulin-related growth factors stimulate proliferation of retinal progenitors in the goldfish. J Comp Neuro/394, 386-94.
BRAISTED, J.E., ESSMAN, T.F. and RAYMOND, P.A. (1994). Selective regeneration of photoreceptors in goldfish retina. Development 120, 2409-19.

BURMEISTER, M., NOVAK, J., LIANG, M.Y., BASU, S., PLODER, L., HAWES, N.L., VIDGEN, D., HOOVER, F., GOLDMAN, D., KALNINS, V.I. et al. (1996). Ocular retardation mouse caused by $\mathrm{Chx10}$ homeobox null allele: impaired retinal progenitor proliferation and bipolar cell differentiation. Nat Genet 12, 376-84.

CASAROSA, S., AMATO, M.A., ANDREAZZOLI, M., GESTRI, G., BARSACCHI, G. and CREMISI, F. (2003). Xrx1 controls proliferation and multipotency of retinal progenitors. Mol Cell Neurosci22, 25-36.

CHACKO, D.M., DAS, A.V., ZHAO, X., JAMES, J., BHATTACHARYA, S. and AHMAD, I. (2003). Transplantation of ocular stem cells: the role of injury in incorporation and differentiation of grafted cells in the retina. Vision Res 43, 937-46.

CHACKO, D.M., ROGERS, J.A., TURNER, J.E. and AHMAD, I. (2000). Survival and differentiation of cultured retinal progenitors transplanted in the subretinal space of the rat. Biochem Biophys Res Commun 268, 842-6.

DOETSCH, F., CAILLE, I., LIM, D.A., GARCIA-VERDUGO, J.M. and A. (1999). Subventricular zone astrocytes are neural stem cells in the adult mammalian brain. Cel/97, 703-16

DORSKY, R.I., RAPAPORT, D.H. and HARRIS, W.A. (1995). Xotch inhibits cell differentiation in the Xenopus retina. Neuron 14, 487-96.

DYER, M.A. and CEPKO, C.L. (2000). Control of Muller glial cell proliferation and activation following retinal injury. Nat Neurosci3, 873-80.

FERDA PERCIN, E., PLODER, L.A., YU, J.J., ARICI, K., HORSFORD, D.J., RUTHERFORD, A., BAPAT, B., COX, D.W., DUNCAN, A.M., KALNINS, V.I. et al. (2000). Human microphthalmia associated with mutations in the retinal homeobox gene $\mathrm{CHX10.}$ Nat Genet 25, 397-401.

FISCHER, A.J., MCGUIRE, C.R., DIERKS, B.D. and REH, T.A. (2002). Insulin and fibroblast growth factor 2 activate a neurogenic program in Muller glia of the chicken retina. $J$ Neurosci22, 9387-98.

FISCHER, A.J. and REH, T.A. (2000). Identification of a Proliferating Marginal Zone of Retinal Progenitors in Postnatal Chickens. Dev Bio/220, 197-210.

FISCHER, A.J. and REH, T.A. (2001). Muller glia are a potential source of neural regeneration in the postnatal chicken retina. Nat Neurosci 4, 247-52.

FISCHER, A.J. and REH, T.A. (2003a). Growth factors induce neurogenesis in the ciliary body. Dev Bio/259, 225-40.

FISCHER, A.J. and REH, T.A. (2003b). Potential of Muller glia to become neurogenic retinal progenitor cells. Glia 43, 70-6.

GALLI, R., GRITTI, A., BONFANTI, L. and VESCOVI, A.L. (2003). Neural stem cells: an overview. Circ Res 92, 598-608.

GAVRIELI, Y., SHERMAN, Y. and BEN-SASSON, S.A. (1992). Identification of programmed cell death in situ via specific labeling of nuclear DNA fragmentation. $\checkmark$ Cell Bio/119, 493-501.

GOLDMAN, S. (2003). Glia as neural progenitor cells. Trends Neurosci26, 590-6.

GOTZ, M., HARTFUSS, E. and MALATESTA, P. (2002). Radial glial cells as neuronal precursors: a new perspective on the correlation of morphology and lineage restriction in the developing cerebral cortex of mice. Brain Res Bul/57, 777-88.

HARRIS, W.A. and PERRON, M. (1998). Molecular recapitulation: the growth of the vertebrate retina. Int J Dev Bio/42, 299-304.

HARUTA, M., KOSAKA, M., KANEGAE, Y., SAITO, I., INOUE, T., KAGEYAMA, R., NISHIDA, A., HONDA, Y. and TAKAHASHI, M. (2001). Induction of phenotypes in adult mammalian iris tissue. Nat Neurosci 4, 1163-4.

HITCHCOCK, P.F., LINDSEY MYHR, K.J., EASTER, S.S., JR., MANGIONE-SMITH, R. and JONES, D.D. (1992). Local regeneration in the retina of the goldfish. $J$ Neurobio/23, 187-203

HITCHCOCK, P.F., MACDONALD, R.E., VANDERYT, J.T. and WILSON, S.W. (1996). Antibodies against Pax6 immunostain amacrine and ganglion cells and neuronalphotoreceptorspecific progenitors, but not rod precursors, in the normal and regenerating retina of the goldfish. JNeurobio/29, 399-413.

HOLLYFIELD, J.G. (1971). Differential growth of the neural retina in Xenopus laevis larvae. Dev Bio/24, 264-86.

HOLT, C.E., GARLICK, N. and CORNEL, E. (1990). Lipofection of cDNAs in the embryonic vertebrate central nervous system. Neuron 4, 203-14.

HUMPHREY, M.F., CONSTABLE, I.J., CHU, Y. and WIFFEN, S. (1993). A quantitative study of the lateral spread of Muller cell responses to retinal lesions in the rabbit. J Comp Neuro/334, 545-58. 
JOHNS, P.R. (1977). Growth of the adult goldfish eye. III. Source of the new retinal cells. J Comp Neuro/176, 343-57.

JOHNS, P.R. (1982). Formation of photoreceptors in larval and adult goldfish. $J$ Neurosci2, 178-98.

JULIAN, D., ENNIS, K. and KORENBROT, J.I. (1998). Birth and fate of proliferative cells in the inner nuclear layer of the mature fish retina. JComp Neuro/394, 27182.

KEEFE, J.R. (1973). An analysis of urodelian retinal regeneration. I. Studies of the cellular source of retinal regeneration in Notophthalmus viridescens utilizing 3 $\mathrm{H}$-thymidine and colchicine. J Exp Zoo/ 184, 185-206.

KICIC, A., SHEN, W.Y., WILSON, A.S., CONSTABLE, I.J., ROBERTSON, T. and RAKOCZY, P.E. (2003). Differentiation of marrow stromal cells into photoreceptors in the rat eye. J Neurosci 23, 7742-9.

KUBO, F., TAKEICHI, M. and NAKAGAWA, S. (2003). Wnt2b controls retinal cell differentiation at the ciliary marginal zone. Development 130, 587-98.

KUBOTA, R., HOKOC, J.N., MOSHIRI, A., MCGUIRE, C. and REH, T.A. (2002). A comparative study of neurogenesis in the retinal ciliary marginal zone of homeothermicvertebrates. Brain Res Dev Brain Res 134, 31-41.

KWAN, A.S., WANG, S. and LUND, R.D. (1999). Photoreceptor layer reconstruction in a rodent model of retinal degeneration. Exp Neuro/159, 21-33.

LAI, K., KASPAR, B.K., GAGE, F.H. and SCHAFFER, D.V. (2003). Sonic hedgehog regulates adult neural progenitor proliferation in vitro and in vivo. Nat NeurosCi 6, 21-7.

LEVINE, E.M., PASSINI, M., HITCHCOCK, P.F., GLASGOW, E. and SCHECHTER, N. (1997). Vsx-1 and Vsx-2: two Chx10-like homeobox genes expressed in overlapping domains in the adult goldfish retina. J Comp Neuro/387, 439-48.

LOLLEY, R.N., RONG, H. and CRAFT, C.M. (1994). Linkage of photoreceptor degeneration by apoptosis with inherited defect in phototransduction. Invest Ophthalmol Vis Sci35, 358-62.

MACHOLD, R., HAYASHI, S., RUTLIN, M., MUZUMDAR, M.D., NERY, S., CORBIN, J.G., GRITLI-LINDE, A., DELLOVADE, T., PORTER, J.A., RUBIN, L.L. et al. (2003). Sonic hedgehog is required for progenitor cell maintenance in telencephalic stem cell niches. Neuron 39, 937-50.

MACK, A.F. and FERNALD, R.D. (1993). Regulation of cell division and rod differentiation in the teleost retina. Brain Res Dev Brain Res 76, 183-7.

MACLAREN, R.E. (1996). Development and role of retinal glia in regeneration of ganglion cells following retinal injury. Br J Ophthalmo/80, 458-64.

MALATESTA, P., HARTFUSS, E. and GOTZ, M. (2000). Isolation of radial glial cells by fluorescent-activated cell sorting reveals a neuronal lineage. Development 127, 5253-63.

MARQUARDT, T., ASHERY-PADAN, R., ANDREJEWSKI, N., SCARDIGLI, R., GUILLEMOT, F. and GRUSS, P. (2001). Pax6 is required for the multipotent state of retinal progenitor cells. Cel/105, 43-55.

MATHERS, P.H., GRINBERG, A., MAHON, K.A. and JAMRICH, M. (1997). The Rx homeobox gene is essential for vertebrate eye development. Nature $387,603-$ 7.

MOORE, K.B., SCHNEIDER, M.L. and VETTER, M.L. (2002). Posttranslational mechanisms control the timing of bHLH function and regulate retinal cell fate. Neuron 34, 183-95

MORRIS, V.B., WYLIE, C.C. and MILES, V.J. (1976). The growth of the chick retina after hatching. Anat Rec 184, 111-3.

MOSHIRI, A. and REH, T.A. (2004). Persistent progenitors at the retinal margin of ptc+/- mice. J Neurosci. 24: 229-37.

MULLOR, J.L., DAHMANE, N., SUN, T. and RUIZ I ALTABA, A. (2001). Wnt signals are targets and mediators of Gli function. Curr Bio/11, 769-73.

NISHIDA, A., TAKAHASHI, M., TANIHARA, H., NAKANO, I., TAKAHASHI, J.B., MIZOGUCHI, A., IDE, C. and HONDA, Y. (2000). Incorporation and differentiation of hippocampus-derived neural stem cells transplanted in injured adult rat retina. Invest Ophthalmol Vis Sci41, 4268-74.

NOCTOR, S.C., FLINT, A.C., WEISSMAN, T.A., DAMMERMAN, R.S. and KRIEGSTEIN, A.R. (2001). Neurons derived from radial glial cells establish radial units in neocortex. Nature 409, 714-20.

OHNUMA, S., HOPPER, S., WANG, K.C., PHILPOTT, A. and HARRIS, W.A. (2002a). retinal histogenesis: early cell cycle exit enhances early cell fate determination in the Xenopus retina. Development 129, 2435-46.
OHNUMA, S., MANN, F., BOY, S., PERRON, M. and HARRIS, W.A. (2002b). Lipofection strategy for the study of Xenopus retinal development. Methods 28, 411-9.

OKABE, M., IMAI, T., KURUSU, M., HIROMI, Y. and OKANO, H. (2001). Translational repression determines a neuronal potential in Drosophila asymmetric cell division. Nature 411, 94-8.

OOTO, S., AKAGI, T., KAGEYAMA, R., AKITA, J., MANDAI, M., HONDA, Y. and TAKAHASHI, M. (2004). Potential for neural regeneration after neurotoxic injury in the adult mammalian retina. Proc Natl Acad Sci USA 101: 13654-9.

OTTESON, D.C., D'COSTA, A.R. and HITCHCOCK, P.F. (2001). Putative stem cells and the lineage of rod photoreceptors in the mature retina of the goldfish. Dev Bio/232, 62-Coordinating 76.

OTTESON, D.C. and HITCHCOCK, P.F. (2003). Stem cells in the teleost retina: persistent neurogenesis and injury-induced regeneration. Vision Res 43, 927-36.

PERRON, M., BOY, S., AMATO, M.A., VICZIAN, A., KOEBERNICK, K., PIELER, T. and HARRIS, W.A. (2003). A novel function for Hedgehog signalling in retinal pigment epithelium differentiation. Development 130, 1565-77.

PERRON, M. and HARRIS, W.A. (2000). Retinal stem cells in vertebrates. Bioessays 22, 685-8

PERRON, M., KANEKAR, S., VETTER, M.L. and HARRIS, W.A. (1998). The genetic sequence of retinal development in the ciliary margin of the Xenopus eye. Dev Bio/199, 185-200.

RAYMOND, P.A. and HITCHCOCK, P.F. (1997). Retinal regeneration: common principles but a diversity of mechanisms. Adv Neuro/72, 171-84.

RAYMOND, P.A. and HITCHCOCK, P.F. (2000). How the neural retina regenerates. Berlin Heidelberg: Springer-Verlag.

REH, T.A. (1987). Cell-specific regulation of neuronal production in the larval frog retina. J Neurosci 7, 3317-24.

REH, T.A. and FISCHER, A.J. (2001). Stem cells in the vertebrate retina. Brain Behav Evol58, 296-305.

REH, T.A. and NAGY, T. (1987). A possible role for the vascular membrane in retinal regeneration in Rana catesbienna tadpoles. Dev Bio/122, 471-82.

REH, T.A. and NAGY, T. (1989). Characterization of Rana germinal neuroepithelial cells in normal and regenerating retina. Neurosci Res Supp/10, S151-61.

REH, T.A. and TULLY, T. (1986). Regulation of tyrosine hydroxylase-containing amacrine cell number in larval frog retina. Dev Bio/114, 463-9.

SAKAKIBARA, S., IMAI, T., HAMAGUCHI, K., OKABE, M., ARUGA, J., NAKAJIMA K., YASUTOMI, D., NAGATA, T., KURIHARA, Y., UESUGI, S. et al. (1996). Mouse-Musashi-1, a neural RNA-binding protein highly enriched in the mammalian CNS stem cell. Dev Bio/176, 230-42.

SAKAKIBARA, S., NAKAMURA, Y., SATOH, H. and OKANO, H. (2001). Rnabinding protein Musashi2: developmentally regulated expression in neural precursor cells and subpopulations of neurons in mammalian CNS. J NeurosCi 21, 8091-107.

SAKAKIBARA, S., NAKAMURA, Y., YOSHIDA, T., SHIBATA, S., KOIKE, M., TAKANO, H., UEDA, S., UCHIYAMA, Y., NODA, T. and OKANO, H. (2002). protein Musashi family: roles for CNS stem cells and a subpopulation of ependymal cells revealed by targeted disruption and antisense ablation. Proc Natl Acad Sci USA 99, 15194-9.

SILVERMAN, M.S., HUGHES, S.E., VALENTINO, T.L. and LIU, Y. (1992). Photoreceptor transplantation: anatomic, electrophysiologic, and behavioral evidence for the functional reconstruction of retinas lacking photoreceptors. Exp Neuro/115, 87-94

STRAZNICKY, K. and GAZE, R.M. (1971). The growth of the retina in Xenopus laevis: an autoradiographic study. J Embryol Exp Morpho/26, 67-79.

TAKAHASHI, M., PALMER, T.D., TAKAHASHI, J. and GAGE, F.H. (1998). Widespread integration and survival of adult-derived neural progenitor cells in the developing optic retina. Mol Cel/ Neurosci 12, 340-8.

TOMITA, M., ADACHI, Y., YAMADA, H., TAKAHASHI, K., KIUCHI, K., OYAIZU, H., IKEBUKURO, K., KANEDA, H., MATSUMURA, M. and IKEHARA, S. (2002). Bone marrow-derived stem cells can differentiate into retinal cells in injured rat retina. Stem Cells 20, 279-83.

TROPEPE, V., COLES, B.L., CHIASSON, B.J., HORSFORD, D.J., ELIA, A.J., MCINNES, RNAbinding R.R. and VAN DER KOOY, D. (2000). Retinal stem cells in the adult mammalian eye. Science 287, 2032-6. 
VANHOFFELEN, S.J., YOUNG, M.J., SHATOS, M.A. and SAKAGUCHI, D.S. (2003). Incorporation of murine brain progenitor cells into the developing mammalian retina. Invest Ophthalmol Vis Sci44, 426-34.

WETTS, R., SERBEDZIJA, G.N. and FRASER, S.E. (1989). Cell lineage analysis reveals multipotent precursors in the ciliary margin of the frog retina. Dev Biol 136, 254-63.

WU, D.M., SCHNEIDERMAN, T., BURGETT, J., GOKHALE, P., BARTHEL, L. and RAYMOND, P.A. (2001). Cones regenerate from retinal stem cells sequestered in the inner nuclear layer of adult goldfish retina. Invest Ophthalmol Vis Sci42, 2115-24.

YOUNG, M.J., RAY, J., WHITELEY, S.J., KLASSEN, H. and GAGE, F.H. (2000).
Neuronal differentiation and morphological integration of hippocampal progenitor cells transplanted to the retina of immature and mature dystrophic rats. Mol Cell Neurosci 16, 197-205.

ZHAO, S., CHEN, Q., HUNG, F.C. and OVERBEEK, P.A. (2002). BMP signaling is required for development of the ciliary body. Development 129, 4435-42.

ZUBER, M.E., GESTRI, G., VICZIAN, A.S., BARSACCHI, G. and HARRIS, W.A. (2003). Specification of the vertebrate eye by a network of eye field transcription factors. Development 130, 5155-67.

ZUBER, M.E., PERRON, M., PHILPOTT, A., BANG, A. and HARRIS, W.A. (1999). Giant eyes in Xenopus laevis by overexpression of XOptx2. Ce//98, 341-52. 